\title{
Production of a Protein Concentrate Based on Maggots of Domestic Flies for the Feeding of Non-ruminant Animals (Burkina Faso)
}

\author{
Timbilfou Kiendrébéogo ${ }^{1 *}$, Isidor Z. Ouédraogo ${ }^{2}$, Drissa Barry ${ }^{3}$, C. Y. Kaboré-Zoungrana ${ }^{4}$ \\ ${ }^{1}$ Institut de l'Environnement et de Recherches Agricoles, \\ Station de Farako-Bâ, Bobo-Dioulasso, Burkina Faso \\ ${ }^{2}$ Université Nazi Boni, Bobo-Dioulasso, Burkina Faso \\ ${ }^{3}$ Université de Dédougou, Dédougou, Burkina Faso \\ ${ }^{4}$ Laboratoire d'Etudes et de Recherches sur les Ressources Naturelles \\ et les Sciences de l'Environnement (LERNSE), Université Nazi \\ *Corresponding author's email : timbilfou [AT] gmail.com
}

\begin{abstract}
The objective of the study was to develop a process for the production of a protein concentrate based on maggots (MC) of domestic fly larvae that can be used in the diet of non-ruminants' animals as pigs and poultry. Maggots were first produced from 3 substrates called S1, S2 and S3. They were then harvested and separated from the substrates using a mesh screen box. Live maggots then incorporated at a rate of $79.15 \%$ by weight in a preconcentrate (20.85\%) composed by $64.80 \%$ of cotton cake and $35.20 \%$ of wheat bran. The resulting MC was then heated in a pan for 5-10 minutes to neutralize the maggots and dried for 24 hours. The results show that the productivity of the S3 substrate (4.91g of maggots / $100 \mathrm{~g}$ of substrate) was significantly lower than the substrates $S 1(6.60 \mathrm{~g} / 100 \mathrm{~g})$ and $\mathrm{S2}$ $(5.35 \mathrm{~g} / 100 \mathrm{~g})(\mathrm{p}<0.05)$. The DM content of the MC was $92.56 \%$. Its nutritional values were $37.69 \% \mathrm{CP}, 5.12 \% \mathrm{FAT}$ and 11.04\% CB. The estimated value in digestible energy was $2238 \mathrm{kcal} / \mathrm{kg}$ DM. The production cost of $01 \mathrm{kgDM}$ of MC of 160FCFA was lower than 240FCFA of the selling price of fishmeal and soya cake (400FCFA) in the local market. MC is an alternative to make low cost protein sources more available. Further studies would evaluate the essential amino acid content of the concentrate and the effectiveness of diets incorporating it into poultry and pigs' production.
\end{abstract}

Keywords-Maggot concentrate, Production process, Nutritional values, Production cost, Burkina Faso.

\section{INTRODUCTION}

Livestock Development in Africa is hampered in large part by insufficient food resources, and especially protein deficiency, which does not always meet the needs of animals [1]. These sources of dietary protein, although very essential for animal feed, are experiencing a surge in prices and are unsustainable [2]. This situation is aggravated by the high cost of food and competition between humans and animals for the same food resources [3], [4], [5].

To address the problems of lack of protein of animal origin in non-ruminant breeding, research has focused on the breeding of insects [7], [2], [8], [9]. They are everywhere, reproduce quickly and are relatively available in all seasons [10], [11]. In addition, they have high growth and feed conversion rates [12]. In this context, maggots have been the subject of several studies that have shown the possibility of producing easily in tropical areas [13], [10] and their use in animal husbandry as a food protein [2]. Orienting research to simple insect breeding techniques will only accelerate the development and use of this resource that does not require large areas for nutrient benefit [14]. Of all the insects used as sources of protein in animal feed, the maggot has the advantage that in sub-Saharan Africa, its production in good quantity is possible from a wide range of household waste, agricultural by-products and animal waste (meat or excrement) [4].

Several studies have shown the effectiveness of several substrates in the production of maggots [5]. Although work has been done on the production of maggots and its use in animal feed [4], [15], In Burkina Faso, alongside Extensive breeding of poultry and pigs, intensified breeding of these 2 species in and around cities is developing. For the successful production of non-ruminant, the incorporation of animal protein into their diet is essential. Apart concentrates imported from elsewhere, raw materials sources of animal protein (fishmeal) or vegetable (cotton cakes, soybeans) are purchased from the provendiers and subsequently incorporated into the rations of animals from intensified farms. 
However, these raw materials are difficult to access because of their high price and especially of frequent breaks in their availability on the market.

In Burkina Faso, the use of domestic fly maggots in poultry feed is known. Maggots are commonly purchased in slaughterhouses in the major urban centers of Ouagadougou and Bobo-Dioulasso where they are produced in slaughter effluents (stomach and intestines contents, blood). They are then distributed alive to poultry from small family farms, as alternative sources of protein. The latter practice has limits because the distribution is done without rational measures, which can constitute a health risk for the beneficiary subjects in case of excess [4]. In addition, the purchase of maggots produced in slaughterhouses can introduce certain diseases on farms, or even entail risks of diseases for the manipulators of these products. In addition, undocumented observations report cases of perforation of chickens' jaws having consumed live maggots.

Excluding maggot flours and living maggots that are used information about other forms such as concentrates are few available. The purpose of this study is to develop a commercially available maggot protein concentrate for partial or total substitution of conventional animal protein sources to help reduce costs and ensure ease of use in rationing pigs and poultry.

\section{MATERIAL AND METHODS}

\section{Presentation of the study site}

The study was conducted at the Farako-Bâ research station in Bobo-Dioulasso (Hauts Bassins Region) in Burkina Faso. Farako-ba is one of the stations of the Institute of Environment and Agricultural Research (INERA). It is located $15 \mathrm{~km}$ south of the town of Bobo-Dioulasso on the road Bobo-Banfora border of Côte d'Ivoire. These geographical coordinates are $04^{\circ} 20$ west longitude and $11^{\circ} 06$ north latitude. It is crossed by the river Houet at an average altitude of $405 \mathrm{~m}$. The climate of the station is South-Sudanian type between 1000 and 1200 isohyets [17].

\section{Production of maggots of domestic fly larvae}

\section{Biological material}

The study aimed to mass-produce maggots of houseflies (Musca domestica) as the main component of the maggot concentrate. To do this, houseflies have been used in the production process. The study aimed to produce a concentrate that can be used by pigs and poultry. The pig excrement of the Farako-bâ - bean pig production unit was used as a basic substrate. This raw material is daily available. This choice makes it possible to avoid transporting foreign substrates to the farm in order to avoid contaminating them. It also makes it possible to valorize the excrement of the farm which makes it possible to reduce the production costs of the maggots. From this raw material, three types of substrate were composed:

- Substrate 1 (S1): pig excrement + industrial draft. Dust of industrial beer at a rate of $2 \mathrm{~kg}$ is used for a first layer arranged in boxes of laying eggs for flies. The dejection of pork (20kg / box) is a second layer above the draft of beer;

- Substrate 2 (S2): This substrate is composed of excrement of pigs without other additives;

- Substrate 3 (S3): This substrate consists of the residue of the first extraction of maggots from substrates 1 and 2. The residue once obtained is rotten for 24 hours. At the end of this time $22 \mathrm{~kg}$ of the substrate / crate is used for the production of maggots.

\section{Seeding boxes}

This is a bottomless wooden box framed (Figure 1) square of $01 \mathrm{~m}$ side. The depth of each crate is $5 \mathrm{~cm}$. Each box thus formed offers $1 \mathrm{~m}^{2}$ of exhibition space and a volume of $0.05 \mathrm{~m} 3$. The boxes are placed on the ground on a black plastic film on which the substrate is deposited (Figure 2).
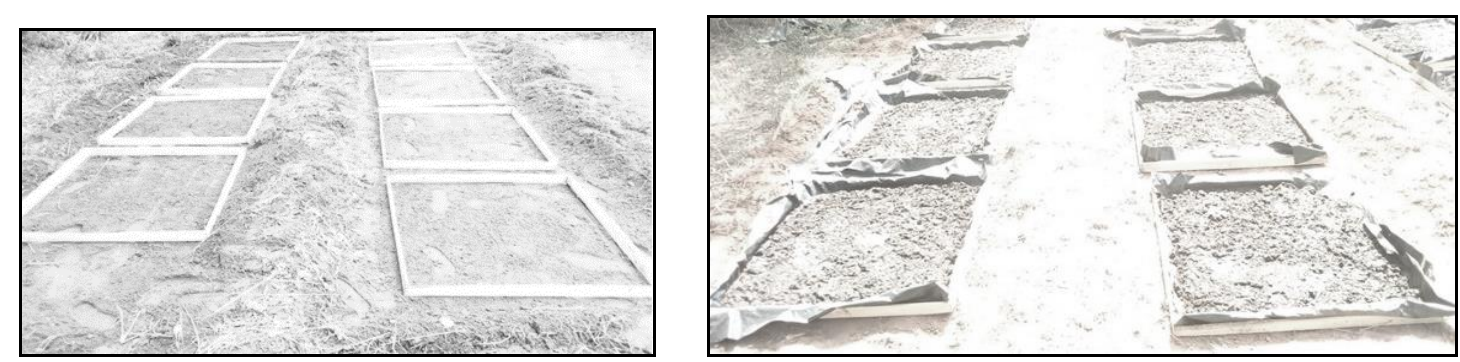

Figure 1: seed box

Figure 1: Box filled with substrate seeded with domestic fly eggs 


\section{Harvesting maggots from substrates}

A sieve box is used to harvest maggots from the substrates. This is a rectangular box mounted at $1 / 2$ man height on 4 supports (Figure). The box is equipped with a mesh cover of $1 \mathrm{~mm}$ mesh, movable by means of pommels to open and closed at will. The bottom of the box is in plywood. It opens on its front side by a sliding drawer in which are collected maggots. Two (2) sieve cabinets of different sizes were used: one of $0.77 \mathrm{~m}^{2}(1.07 \mathrm{~m} \times 0.715 \mathrm{~m})$ and a second one of $1.2 \mathrm{~m}^{2}(1.2 \mathrm{~m} \times 1 \mathrm{~m})$ (Figure 3 and 4$)$. The extraction of the maggots took place on the 4th day of the incubation. At the time of collection of the maggots, the substrate containing the maggots is progressively trenched with a trowel, exposing them to the light that causes them to migrate to the bottom of the container. When it is judged that the maximum of substrate is separated from the maggots, the maggots and the residual substrate are progressively reversed on the mesh screen of the box. The extraction process is based on the photophobic behavior of maggots that in contact with light migrate to the bottom. Wanting to migrate to the bottom they cross the fence and fall into the collecting drawer. After the desiccation of all moving shears, the collecting tray is removed and the fresh larvae harvested per case are weighed.

Production of maggots of domestic fly larvae

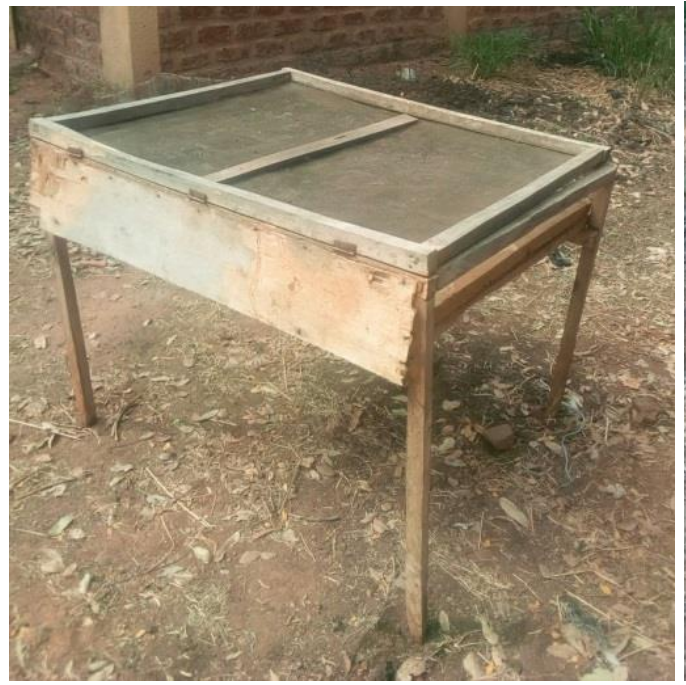

Figure 3: Sieve box seen from back and profile

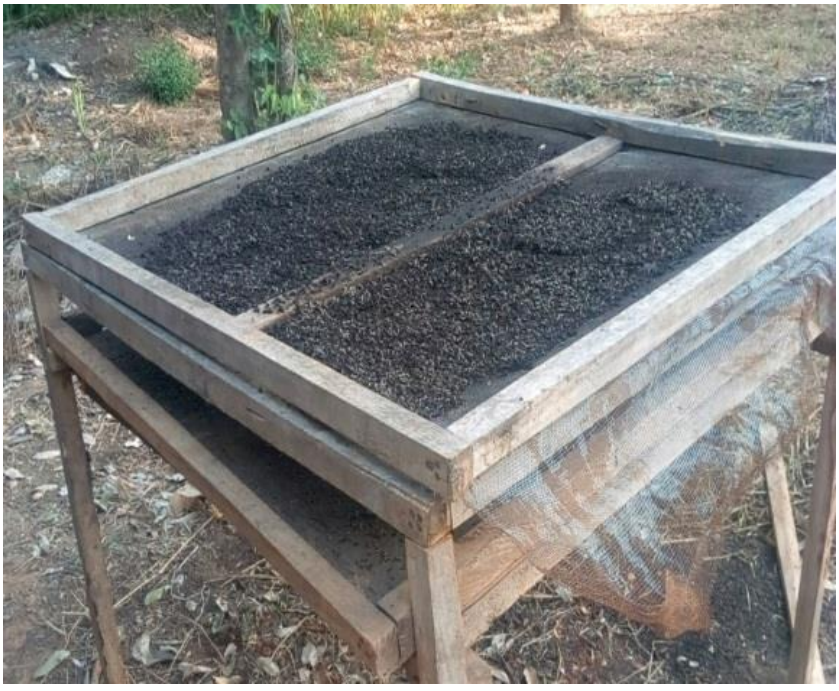

Figure 4: Sieve box seen from the front and in profile

\section{Production of maggot concentrate}

Maggot concentrate is produced on the basis of a premix of $64.75 \%$ cotton cake and $35.25 \%$ wheat bran. The maggots collected are weighed and a quantity representing $79.15 \%$ of the fresh concentrate is incorporated into the premix. The fresh concentrate obtained is poured into a skillet which will be brought to the fire for 5 to 10 minutes to neutralize the maggots under the effect of heat. During heating, a wooden spatula is used to stir the concentrate to ensure a good mixture while avoiding that the maggots are calcined. The fresh concentrate obtained is then dried in the sun for 24 hours and then finely ground.

\section{RESULTS}

\section{Productivity in maggots of different substrates}

The average productivity in maggots of the different substrates is presented in Table 1 . The mean weights of maggots per box and per 100g of substrates S1, S2 and S3 were in the order significantly different and decreasing (p $<0.05)$. Figures 5, 6 and 7 show the fly larvae in the substrate, maggot concentrate in the fresh and dried concentrate. 


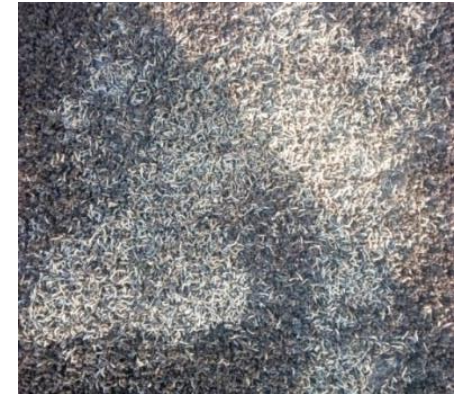

Figure 5: Fly larvae after stripping superficial substrate

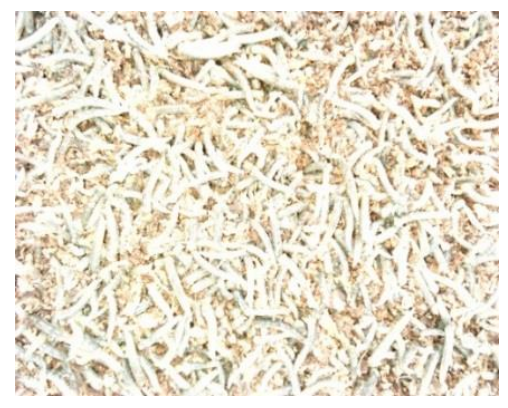

Figure 6; Maggot concentrate just after neutralization of the larvae

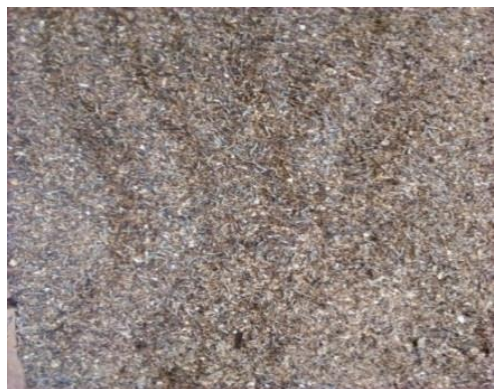

Figure 7: Concentrated dried maggots

\section{Food values of maggot concentrate and raw materials}

The results presented in Table 2 show that maggot concentrate is rich in crude nitrogenous matter (MAT) and digestible energy (ED). They contain other nutrients such as fat (MG) and crude fiber.

Table 1: Maggot productivity following the type of substrate

\begin{tabular}{lccc}
\hline \multirow{2}{*}{ Parameters } & \multicolumn{3}{c}{ Substrates of production } \\
\cline { 2 - 4 } & $\mathrm{S} 1$ & $\mathrm{~S} 2$ & $\mathrm{~S} 3$ \\
\hline Average weight per trap $(\mathrm{g})$ & $1,449.89 \pm 54.84^{\mathrm{a}}$ & $1,175.93 \pm 144,37^{\mathrm{ab}}$ & $1,079.62 \pm 66.49^{\mathrm{b}}$ \\
Average weight / 100g of substrate & $6.60 \pm 0.25^{\mathrm{a}}$ & $5.35 \pm 0,65^{\mathrm{ab}}$ & $4.91 \pm 0.30^{\mathrm{b}}$ \\
\hline
\end{tabular}

- S1: Pigs' excrement + industrial draft; - S2: Excrement of pigs without other additives; - S3: Residue of the first extraction of maggots from S1 and $\mathrm{S} 2$.

* Average values with the same letter on the same line are not significantly different $(\mathrm{p}<0,05)$

\section{Food values of maggot concentrate and maggot flour}

The results presented in Table 2 show that maggot concentrate has concentrated lower levels of CP and Fat than of maggot meal. At the fibers level the NDF content was higher for the AC than of the maggot flour. Maggot concentrate contained more metabolizable energy $(+23.63 \%)$ than of maggot flour.

Table 2: Chemical composition (\% DM) of maggot concentrate and maggot meal and their metabolizable energy content $(\mathrm{kcal} / \mathrm{kg} \mathrm{DM})$

\begin{tabular}{lcc}
\hline \multirow{2}{*}{ Parameters } & \multicolumn{2}{c}{ Feed } \\
\cline { 2 - 3 } & Maggot concentrated & Maggot Floor \\
\hline Crude protein & 37,69 & 40,97 \\
Fat & 5,12 & 10,3 \\
Crude cellular (\%MS) & 11,04 & 16,02 \\
NDF & 50,4 & 36,96 \\
ADF & 15,08 & 18,61 \\
Lignin & 4,37 & 5,54 \\
Mineral matter (\%) & 12,72 & 19,01 \\
NaCl & 2,14 & 1,01 \\
Calcium & 0,08 & 0,07 \\
Metabolizable energy (kcal/kgMS) & 2731 & 2227 \\
Phosphorus & 0,32 & 0,27 \\
\hline
\end{tabular}




\section{DISCUSSION AND CONCLUSION}

\section{Productivity of maggot's different substrates}

The study led to the development of a feed concentrate production process for mon-ruminant based on larvae of houseflies (Musca domestica) or maggots. It also made it possible to test the productivity of substrates available in the pig rearing unit, namely pig excrements (S2) and pig excrements combined with industrial draft distillers (S1). Our results show that the weight productivity in maggots of the three substrates per $100 \mathrm{~g}$ of substrate is higher than that of $4.47 \mathrm{~g}$ reported by [15] for a substrate made of pork manure. The productivities of the three substrates were different from those of many substrates reported by [5]. In fact, they are higher than those of so-called substrates: leftover pineapple walls, remains of fresh fish and guts of rabbits, mixture of peelings and raw pieces of yam, remains of fresh fish, fresh guts of rabbits and rest and ripe banana peel, Mix of peelings and raw pieces of yam, leftover ripe pineapple, leftover fresh fish and peelings. On the other hand, it was less important than those of other substrates made up of fresh fish remains (guts); raw meat of rat and mixture of fresh fish waste and fresh rabbit guts used by these same authors. The latter substrates could be coveted because of their higher productivity but we can be dissuaded by the nature of their components that are almost to look on the market and if hygiene measures are not taken these substrates can be a source of disease. Unlike pig excrements that are available at the level of the production unit

\section{Food values of maggot concentrate}

Nutritional analyzes show that maggot concentrate is an important source of protein. However, its crude protein (CP) content is lower than the values between $40 \%$ and $50 \%$ of the DM of maggot meal reported by several authors [17] and fish. (Letard, undated). This content is also lower than that of vegetable protein sources, such as the cotton cake used in our process, which accounts for more than 50\% DM [18] and peanut cake (Letard, undated). Wheat bran, which is also one of its components, has a much higher CP content than wheat bran, which is generally between 15 and $16 \%$ DM, according to the results reported by [19]. in CP of the lower MC than those of the main sources of animal and plant protein mentioned above is due to the weighting of wheat bran with a $\mathrm{CP}$ content of more than 1.40 times lower. The $\mathrm{CP}$ content of the CM is not a linear average of the raw materials of which it is composed which would have been less than 7 points. The crude fiber (CF) content of the $\mathrm{MC}$ is almost comparable to that of cottonseed meal and bran. Wheat is found in as the addition of these other two ingredients gives a DC content of the MC that is about 6 percentage points lower than that of maggot meal. This content of DC maggot meal is close to the limit of $10 \%$, a level not to be exceeded in the rationing of pigs and poultry. This indicates that $\mathrm{MC}$ from this point of view will be more beneficial to monogastric compared to pure maggot meal $(16 \% \mathrm{DC})$. The production of MC makes it possible to reduce the contents of ADF, NDF and $\mathrm{CB}$ in better proportions to allow its good incorporation in the monogastric rations. Our results show that MC has a good digestible energy content $(2237.74 \mathrm{kcal} / \mathrm{kg} \mathrm{DM})$. This energy content alone is sufficient to meet the energy requirement of a pork weighing less than $15 \mathrm{~kg}$ live weight [20].

In conclusion the study developed a process for the production of a maggot-based protein concentrate for the rationing of non-ruminants, especially pigs and poultry. It also showed that it was possible to produce the maggots necessary for the formulation of the concentrate by recycling the available pig excrements on the farm. The process has mainly produced a concentrate of good nutritional and energy values, but especially at a lower cost than the sources of animal and vegetable proteins commonly used in intensives pigs and poultry farming. It also allowed to obtain a concentrate with lower contents of CC and ADF compared to those of the flour of maggot. This last characteristic augurs a good digestibility of rations that would incorporate them. It would be necessary to evaluate the effectiveness of using diets incorporating maggot concentrate in the rationing of pigs and poultry.

\section{REFERENCES}

[1] Loa C 2000. Production et utilisation contrôlées d'asticots. Tropicultura. 18, 4, 215-219.

[2] Pomalégni S. C. B., Gbemavo D. S. J. C., Babatoundé S., Chrysostome C. A. A. M., Koudandé O. D., Glèlè Kakaï R. L., Mensah G. A., 2016. Synthèse bibliographique sur les insectes et autres invertébrés comestibles utilisés dans l'alimentation des animaux monogastriques d'élevage. Bulletin de la Recherche Agronomique du Bénin (BRAB), Numéro 80: 43-53.

[3] Mpoame M., Téguia A. et Nguemfo E. L, 2004: Essai comparé de production d'asticots dans les fientes de poule et dans la bouse de vache. Tropicultura, 22, (2): 84-87

[4] Bouafou K.G.M., Konan B. A., Meite A. 2, Kouame K.G., Katy-Coulibally.S., 2011. Détermination du taux optimal de farine d'asticots séchés dans le régime du rat en croissance. Journal of Animal \& Plant Sciences, 2011. Vol. 12, Issue 2: 1553-1559.

[5] Bouafou K.G.M., Kouame K.G., Amoikon E.K and Offoumou A.M., 2006. Potentiels pour la production d'asticots sur des sous-produits en Côte d'Ivoire. Tropicultura (24): 157-161.

[6] Bouafou K.G.M., Kouame K.G., Offoumou A.M., 2007. Bilan azoté chez le rat en croissance de la farine d'asticots séchés. Tropicultura (25) : 70-74. 
[7] Ouédraogo S., 2016: Contribution à l'étude sur l'utilisation des termites (Macrotermes sp) en aviculture traditionnelle au Burkina Faso. Mémoire d'ingénieur du Développement Rural, option Elevage. IDR, l’Université Polytechnique de Bobo-Dioulasso, Burkina Faso.

[8] Zongo G. Z., 2017: Contribution à l'étude sur l'utilisation des larves de mouches (Musca domestica) dans l'alimentation des poulets locaux au Burkina Faso. Mémoire d'ingénieur du Développement Rural, option Elevage. IDR, Université Nazi Boni. 63p.

[9] Mangunga E 2013 Synthèse des travaux de recherches sur la production d'asticots pour l'alimentation desmonogastriques (cas de la volaille et de rongeur). Travail de fin de cycle présenté en vue de l'obtention du titre de graduation en médecine vétérinaire, $6 \mathrm{p}$.

[10] Sanou, C. L., Tsado, D. N., Kiema, A., Eichie, J. O., \& Okhimamhe,A. A. (2018). Variabilité climatique et stratégies d'adaptation à la rentabilité: les défis de la mobilité du bétail dans le sud-est du Burkina Faso. Open Acess Library Journal, 5 (e4372), 16.

[11] Sankara F., Pousga S., Dao N.C.A, Gbemovo D.S.J.C, Clotey V.A, Coulibaly K, Nacoulma J.P, Ouédraogo S., Kenis M., 2018. Savoir autochtones et potentiel des termites pour l'alimentation des volailles au Burkina Faso. Journal of insects as food and feed: 4 (4). P211-218.

[12] Van H. A., Van I. J., Klunder H., Mertens E, Halloran A., Muir G., Vantomme P., 2013. Edible Insects: Future prospects for food and feed security. FAO Forestry paper 171. Rome.

[13] Pomalégni S.C.B., 2017. Perceptions, performances zootechniques et qualité nutritionnelle de la viande de poulets locaux (Gallus gallus) nourris avec des rations alimentaires à base de larves de mouche (Musca domestica, Linnaeus 1758) au Bénin. Thèse de Doctorat, Université d'Abomey-Calavi. 260 p.

[14] Lenga A., Baghamboula L. E.et Vouidibio J., 2012: Fragmentation d'un écosystème Littoral: cas de la baie de Loango au

[15] Tendonkeng F., Miégoué E., Lemoufouet J., Mouchili M., Matimuini1 N.F., Mboko1 A.V., Fogang Zogang B., Mweugang N.N., Zougou1 T.G., Boukila1 B. et Pamo T.E., 2017. Production et composition chimique des asticots en fonction du type de substrat. Laboratoire de Nutrition Animale, Département des Productions Animales, FASA, Université de Dschang, B.P. 222 Dschang, Cameroun.P9.

[16] Guinko S., 1984. Végétation de la Haute Volta. Thèse de doctorat. Sciences naturelles. Université de Bordeaux III. 2 tomes, 394 pages + annexes. Congo-Brazzaville. Int. J. Biol. Chem. Sci., 6 (5): 2113-2130.

[17] Ajani E.K., Nwanna 1.c. and Musa B.o., 2004. Replacement of fishmeal with maggot meal in the diets of Nile tilapia, Oreochromis niloticus. World aquaculture. P 52-59.

https://www.researchgate.net/profile/Emmanuel_Ajani/publication/288267764_Replacement_of fishmeal_with_maggot _meal_in the diets of Nile tilapia_Oreochromis niloticus/links/5cad5cc4a6fdccfa0e7ddbfc/Replacement-of-fishmealwith-maggot-meal-in-the-diets-of-Nile-tilapia-Oreochromis-niloticus.pdf.

[18] Diomandé M., Allou Kippré V., Koussémon M.et Kaménan A., 2008. Substitution de la farine de poisson par celle d'escargot (Achatina fulica) dans l'alimentation des poules pondeuses en Côte d'Ivoire. Livestock Research for Rural Development. Volume 20, Article \#2. Retrieved October 4, 2019, from http://www.lrrd.org/lrrd20/1/diom20002.htm [19] Boudouma D 2009: Composition chimique du son de blé dur produit par les moulins industriels algériens. Livestock Research for Rural Development. Volume 21, Article \#167. Retrieved October 4, 2019, from http://www.lrrd.org/llrd21/10/boud21167.htm

[20] Chaloub Y., 1989. Guide pratique d'alimentation des monogastriques, porcs, lapins, volailles. 